\begin{tabular}{|c|c|}
\hline furnal Kesmas Untika Luwuk: Public Health Journal & 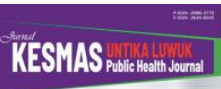 \\
\hline Volume 11, Nomor 2, Desember 2020 & \\
\hline P-ISSN: 2086-3773, E-ISSN: 2620-8245 & \\
\hline Website: https://journal.fkm-untika.ac.id/index.php/phj & \\
\hline This work is licensed under a Creative Commons Attribution 4.0 International License. & $8=$ \\
\hline
\end{tabular}

\title{
Faktor yang Berhubungan dengan Kejadian Dehidrasi pada Pekerja Tempe di Kelurahan Rajawali Kota Jambi
}

\author{
(Factors Related to Dehydration Events of Tempe Workers in Kelurahan \\ Rajawali, Kota Jambi)
}

Novitri Sari ${ }^{1}$, Entianopa ${ }^{1 *}$, Eko Mirsiyanto ${ }^{1}$

${ }^{1}$ Sekolah Tinggi Ilmu Kesehatan Harapan Ibu Jambi

* Koreponden Penulis : entianopa23@gmail.com

\begin{abstract}
ABSTRAK
Dehidrasi merupakan kekurangan cairan tubuh karena jumlah cairan yang keluar lebih banyak dari pada jumlah cairan yang masuk. Salah satu pekerjaan yang beresiko mengalami dehidrasi adalah pada perebusan pembuatan tempe dimana menggunakan lingkungan yang cukup panas sehingga banyak mengeluarkan keringat dan mebutuhkan asupan cairan yang lebih. Tujuan penelitian adalah untuk mengetahui faktor-faktor yang berhubungan dengan kejadian dehidrasi pada pekerja pengrajin tempe. Penelitian ini merupakan penelitian deskriptif analitik dengan pendekatan cross sectional. Populasi dalam penelitian ini adalah seluruh jumlah pengrajin tempe. Sampel berjumlah 30 responden. Teknik pengambilan sampel dengan cara total sampling. Analisis data dalam penelitian ini secara univariat dan bivariat dengan uji chi square. Hasil penelitian ada hubungan konsumsi cairan $(0,004)$ dan beban kerja $(0,007)$ dengan kejadian dehidrasi pada pekerja pengrajin tempe. Tidak ada hubungan berat badan dengan kejadian dehidrasi pada pekerja pengrajin tempe $(p=0,875)$. Diharapkan pemilik usaha pengrajin tempe untuk dapat selalu menyediakan air minum yang cukup bagi pekerjanya saat pekerja membutuhkan sehingga kejadian dehidrasi dan dampaknya dapat diminimalisir.
\end{abstract}

Kata Kunci : Dehidrasi, konsumsi cairan, beban kerja dan status gizi

\section{ABSTRACT}

Dehydration is a lack of body fluids because the amount of fluid that comes out is more than the amount of fluid that is entered. One of the jobs that are at risk of dehydration is in boiling the manufacture of tempeh which uses a hot enough environment so that you sweat a lot and require more fluid intake. The research objective was to determine the factors associated with the incidence of dehydration in tempe craftsmen. This research is a descriptive analytic study with a cross sectional approach. The population in this study were all of the tempe craftsmen. The sample is 30 respondents. The sampling technique was total sampling. Data analysis in this study was univariate and bivariate with the chi square test. The results showed a relationship between fluid consumption (0.004) and workload (0.007) with the incidence of dehydration among workers of tempe craftsmen. There is no correlation between body weight and dehydration in tempe craftsmen workers ( $p=0.875)$. It is expected that the tempe craftsman business owners can always provide sufficient drinking water for their workers when they need them so that the incidence of dehydration and its impact can be minimized.

Keywords : Dehydration, fluid consumption, workload and nutritional status 



\section{PENDAHULUAN}

Air minum, yang harus dikonsumsi untuk orang dewasa adalah 2 liter atau setara 8 gelas setiap hari. Anjuran ini tidak jauh berbeda dari pernyataan pakar enzim dan guru besar kedokteran di Albert Einsten College Of Medicine USA. Selain itu, kebutuhan cairan saat bekerja akan meningkat dan direkomendasikan sedikitnya 2,3 sampai 3 liter air per hari menurut Dietary Reference Intake (DRI) (Departemen Kesehatan, 2016).

Penelitian lain di Hongkong menunjukkan hasil yang sama bahwa 50\% sampel minum air kurang, dan bahkan 30\% diantaranya minum kurang dari 5 gelas dalam satu hari. Penelitian di Indonesia yang dilakukan di Kota Bogor tentang kebiasaan minum dan asupan cairan, ditemukan bahwa terdapat 37,3\% yang minum kurang dari 8 gelas per hari dan sebesar $24,1 \%$ asupan cairannya kurang dari $90 \%$ kebutuhan (Ratnasari \& Soekatri, 2014)

Beberapa dampak dehidrasi berupa dehidrasi ringan dapat mempengaruhi fungsi kognitif yang menurunkan akuransi kinerja seseorang. Dehidrasi sedang dapat menyebabkan nyeri kepala, gangguan kognitif dan mual. Dehidrasi berat dapat menimbulkan takikardi, pusing, dan lemas yang menghilangkan kemampuan fisik seseorang (Barasi. M, 2010)

Pada umumnya dehidrasi ini disebabkan oleh kebiasaan konsumsi cairan yang kurang dan kehilangan cairan yang berlebihan. Cairan tubuh tersebut hilang melalui urin, feses, kulit, dan pernapasan yang apabila tidak diganti dalam waktu lama akan menurunkan volume plasma serta kemampuan fisik menjadi terganggu. Dehidrasi sebagai salah satu status hidrasi tubuh dapat diketahui melalui pemeriksaan berat jenis urin (BJU) dan pemeriksaan urin sendiri (PURI) dimana kedua pemeriksaan ini paling sering digunakan serta cenderung mudah untuk dilakukan (Barasi. M, 2010)

Selain itu, aktivitas fisik yang meningkat dan tidak diimbangi dengan upaya untuk mengatasi kehilangan cairan tersebut, tentu akan mempermudah keadaan dehidrasi. Aktivitas fisik selalu mengeluarkan cairan dalam bentuk keringat, urin, feses dan pernapasan. Ketika aktivitas fisik seseorang meningkat maka pengeluaran cairan melalui keringat akan lebih cepat daripada kemampuan lambung dalam menampung penggantian cairan sehingga tubuh lebih mudah mengalami dehidrasi (Diyani, 2012).

Salah satu pekerjaan yang membutuhkan minum lebih banyak adalah pada perebusan pembuatan tempe dimana menggunakan lingkungan yang cukup panas sehingga banyak mengeluarkan keringat dan mebutuhkan asupan cairan yang lebih. di kota Jambi terdapat 58 pengrajin tempe yang tersebar di beberapa kelurahan. Peneliti telah melakukan survei pada 10 pekerja pengrajin tempe ditemukan masalah-masalah diantaranya adanya gerakan monoton yang cukup lama ketika bekerja, pekerja sering merasakan nyeri di bagian punggung, lemah,lesu, bibir atau mulut terasa kering, dan juga merasakan pusing ketika duduk atau berdiri. Konsumsi cairan (air minum) yang cukup yaitu minimal 2 liter dalam 1 hari sangat dibutuhkan oleh tubuh hal ini dikarenakan menjaga keseimbangan cairan didalam tubuh sehingga dapat mencegah terjadinya dehidrasi. Dari latar belakang diatas diketahui tujuan khususnya mengetahui gambaran dari konsumsi cairan, status gizi, beban kerja dan dehidrasi pada pekerja pengrajin tempe. 


\section{METODE PENELITIAN}

Dalam kerangka konsep ini yang terjadi variabel independen yaitu konsumsi cairan, status gizi dan beban kerja sedangkan yang menjadi variabel dependen yaitu dehidrasi.

Penelitian ini merupakan penelitian deskriptif analitik dengan pendekatan cross sectional untuk melihat faktor-faktor yang berhubungan dengan kejadian dehidrasi pada pekerja pengrajin Tempe. dalam kerangka konsep ini yang terjadi variabel independen yaitu konsumsi cairan, status gizi dan beban kerja sedangkan yang menjadi variabel dependen yaitu dehidrasi. Penelitian ini dilakukan pada tanggal 07 september 2020 s/d 14 september 2020 di Kelurahan Rajawali Kecamatan Jambi Timur Kota Jambi. Populasi dalam penelitian ini adalah seluruh jumlah pengrajin tempe di kelurahan rajawali tahun 2019 sebanyak 40 pekerja. Sampel dalam penelitian ini berjumlah 30 responden. Teknik pengambilan sampel dilakukan dengan cara total sampling. Analisa data dalam penelitian ini secara Univariat dan Bivariat dengan uji chi square.

\section{HASIL}

Hasil penelitian menunjukkan bahwa konsumsi cairan pekerja pengrajin tempe di Kelurahan Rajawali Kecamatan Jambi Timur Kota Jambi tahun 2020 sebagian besar dalam kategori tidak sesuai kebutuhan $(60,0 \%)$, beban kerja sebagian besar dalam kategori ringan $(73,3 \%)$, status gizi sebagian besar dalam kategori normal $(66,7 \%)$ dan kejadian dehidrasi sebagian besar dalam kategori dehidrasi ringan (53,3\%).

Hasil analisis bivariat menunjukkan bahwa ada hubungan konsumsi cairan $(0,004)$ dan beban kerja $(0,007)$ dengan kejadian dehidrasi pada pekerja pengrajin tempe. Tidak ada hubungan berat badan dengan kejadian dehidrasi pada pekerja pengrajin tempe $(p=0,875)$

Tabel 1.

Gambaran Konsumsi Cairan, Beban Kerja, Status Gizi dan Kejadian Dehidrasi pada pekerja pengrajin tempe di Kelurahan Rajawali Kecamatan Jambi Timur Kota Jambi

\begin{tabular}{lcc}
\hline \multicolumn{1}{c}{ Variabel } & Jumlah & \% \\
\hline Konsumsi Cairan & 12 & \\
$\quad$ Sesuai Kebutuhan & 18 & 40.0 \\
$\quad$ Tidak Sesuai Kebutuhan & & 60.0 \\
Beban Kerja & 22 & 73.3 \\
$\quad$ Ringan & 8 & 26.7 \\
$\quad$ Berat & 5 & \\
Status Gizi & 20 & 16.7 \\
$\quad$ Kurus & 5 & 66.7 \\
$\quad$ Normal & & 16.7 \\
$\quad$ Gemuk & 14 & 46.7 \\
Dehidrasi & 16 & 53.3 \\
$\quad$ Tidak Dehidrasi & &
\end{tabular}

Sumber Data : Data Primer 
46 | Jurnal Kesmas Untika: Public Health Journal, 11 (2): 43-48

Tabel 2.

Hubungan Konsumsi Cairan, Beban Kerja dan Status Gizi dengan Kejadian Dehidrasi pada Pekerja Pengrajin Tempe di Kelurahan Rajawali Kecamatan Jambi Timur Kota Jambi tahun 2020

\begin{tabular}{|c|c|c|c|c|c|c|c|}
\hline \multirow{3}{*}{ Konsumsi Cairan } & \multicolumn{4}{|c|}{ Dehidrasi } & \multirow{2}{*}{\multicolumn{2}{|c|}{ Jumlah }} & \multirow{3}{*}{$\begin{array}{c}P \\
\text { Value }\end{array}$} \\
\hline & \multicolumn{2}{|c|}{$\begin{array}{c}\text { Tidak } \\
\text { Dehidrasi }\end{array}$} & \multicolumn{2}{|c|}{$\begin{array}{c}\text { Dehidrasi } \\
\text { Ringan }\end{array}$} & & & \\
\hline & $\mathbf{n}$ & $\%$ & $\mathbf{N}$ & $\%$ & $\mathbf{n}$ & $\%$ & \\
\hline \multicolumn{8}{|l|}{ Konsumsi Cairan } \\
\hline Sesuai Kebutuhan & 10 & 83.3 & 2 & 16.7 & 12 & 100 & \\
\hline Tidak Sesuai Kebutuhan & 4 & 22.2 & 14 & 77.8 & 18 & 100 & 0.004 \\
\hline \multicolumn{8}{|l|}{ Beban Kerja } \\
\hline Ringan & 14 & 63.6 & 8 & 36.4 & 22 & 100 & \\
\hline Berat & 0 & 0.0 & 8 & 100.0 & 8 & 100 & 0.007 \\
\hline \multicolumn{8}{|l|}{ Status Gizi } \\
\hline Kurus & 2 & 40.0 & 3 & 60.0 & 5 & 100 & \\
\hline Normal & 10 & 50.0 & 10 & 50.0 & 20 & 100 & 0.875 \\
\hline \multirow[t]{2}{*}{ Gemuk } & 2 & 40.0 & 3 & 60.0 & 5 & 100 & \\
\hline & 14 & 46.7 & 16 & 53.3 & 30 & 100 & \\
\hline
\end{tabular}

Sumber Data : Data Primer

\section{PEMBAHASAN}

Hasil penelitian ini sejalan dengan penelitian Huda \& Suwandi yang menemukan hasil bahwa adanya hubungan konsumsi cairan dengan pekerja di Pabrik Tahu UD Sumber Kencana. Konsumsi cairan pada pekerja di Pabrik Tahu UD Sumber Kencana memiliki hubungan yang sangat kuat dengan tingkat dehidrasi, dengan nilai koefisien korelasi (r) sebesar 0,882 (Huda \& Suwandi, 2018).

Konsumsi air dari sumber makanan dan minuman sangat dibutuhkan oleh tubuh untuk proses sirkulasi dalam tubuh untuk transport sel dan pengatur suhu tubuh, apabila air yang keluar tidak digantikan dengan jumlah cairan yang cukup maka akan mengakibatkan sel-sel kehilangan air, kehilangan air inilah yang akan menyebabkan dehidrasi (Brenna H. 2012, 2012)

Menurut asumsi peneliti, secara terus-menerus tubuh manusia mengeluarkan cairan melalui proses pernapasan, buang air kecil dan besar serta ketika berkeringat melalui kulit. Karena itu, setiap orang harus mengganti cairan yang keluar dari tubuh tersebut, tentunya dengan mengonsumsi cairan.

Berdasarkan uraian di atas, peneliti berpendapat bahwa sekitar dua per tiga tubuh manusia terdiri dari air. Untuk menjaga fungsi dan cairan tubuh, manusia perlu mengonsumsi air yang cukup. Kekurangan cairan tubuh atau dehidrasi dapat menyebabkan gangguan fungsi tubuh, mulai dari gangguan ringan hingga gangguan berat yang mengancam nyawa. Dehidrasi ini dapat terjadi karena kurangnya cairan yang masuk dan terlalu banyak cairan yang keluar dari tubuh, seperti muntah, diare, demam, dan keringat berlebih pada cuaca yang sangat panas saat bekerja maupun beraktivitas. 
Oleh karena itu, melihat eratnya hubungan konsumsi cairan dengan kejadian dehidrasi, maka peneliti menyarankan pada pekerja pengrajin tempe di Kelurahan Rajawali untuk dapat mengikuti anjuran petugas kesehatan yang ada di Puskesmas di Keluarahan Rajawali untuk memenuhi konsumsi cairan setiap harinya, diharapkan pula petugas kesehatan untuk membuat spanduk yang berisi tentang informasi kebutuhan cairan pada manusia. Peneliti juga berharap kepada pemilik usaha untuk selalu menyediakan air minum yang cukup bagi pekerjanya saat pekerja membutuhkan sehingga kejadian dehidrasi dan dampaknya dapat diminimalisir.

Hasil penelitian ini sejalan dengan penelitian Huda \& Suwandi yang menemukan hasil bahwa adanya hubungan beban kerja pekerja di Pabrik Tahu dengan kejadian dehidrasi $(p=0,009)$ (Huda \& Suwandi, 2018). Selanjutnya penelitian Tarwiyanti juga menemukan hasil bahwa adanya hubungan beban kerja pekerja di Pabrik Tahu UD Sumber Kencana dengan kejadian dehidrasi $(p=0,003)$ (Tarwiyanti et al., 2020).

Beban kerja juga dapat menyebabkan pekerja mengalami dehidrasi. Jika beban kerja seseorang meningkat maka panas metabolisme yang dihasilkan tubuh juga meningkat. Pekerja yang memiliki beban kerja berat, kemudian ditambah sedang berada di lingkungan kerja yang panas, maka pekerja dapat engalami dehidrasi (Fajriani, A., \& Septiari, 2015).

Saat tenaga kerja bekerja atau menerima beban kerja dan berada di bawah pengaruh lingkungan kerja yang panas, maka kecepatan berkeringat menjadi maksimum. Kondisi tubuh yang seperti ini akan mengalami kehilangan garam-garam mineral, sehingga tubuh mengalami dehidrasi.

Berdasarkan uraian di atas, menurut asumsi peneliti, setiap pekerja pengrajin tempe di Kelurahan Rajawali memiliki beban kerja yang berbeda, dari beban kerja ringan hingga berat. Dehidrasi terjadi dikarenakan pengeluaran cairan tubuh yang lebih besar daripada cairan yang masuk, semakin tinggi beban kerja pekerja, maka akan semakin besar jumlah cairan tubuh yang keluar. Oleh Karena itu, agar pekerja terhindar dari dehidrasi yang disebabkan oleh beban kerja, maka peneltiti menyarankan pada pekerja untuk selalu menyiapkan air minum yang cukup selama bekerja. Diharapkan pula pada pihak yang mempekerjakan pengrajin agar dapat memenuhi kebutuhan cairan seluruh pekerjanya.

Hasil penelitian ini sejalan dengan penelitian Randa dkk yang menemukan hasil bahwa tidak adanya hubungan yang signifikan antara status gizi karyawan PT. Sumber Natural Indonesia dengan kejadian dehidrasi $(\mathrm{p}=0,307)$ (Randa, R., Gifari, N., Nuzrina, R., \& Kuswari, 2018).

Menurut asumsi peneliti, untuk membuat kedelai menjadi tempe melewati proses dari merebus kedelai hingga pemeraman, mereka bekerja dari pagi hingga siang, oleh karena itu maka sangat wajar jika pekerja mengalami dehidrasi ringan, baik pada responden dengan status gizi normal maupun tidak.

Meskipun tidak ditemukan hubungan yang signifikan antara status gizi dengan kejadian dehidrasi pada pekerja pengrajin tempe di Kelurahan Rajawali, namun pekerja sebaiknya tetap menjaga kondisi kesehatannya, menjaga asupan gizi untuk tubuhnya karena dengan gizi yang baik dapat membantu meningkatkan daya tubuh dalam melawan berbagai serangan bibit penyakit. 
48 | Jurnal Kesmas Untika: Public Health Journal, 11 (2): 43-48

\section{KESIMPULAN DAN SARAN}

Berdasarkan hasil penelitian dapat disimpulkan bahwa faktor-faktor yang berhubungan dengan kejadian dehidrasi pada pekerja pengrajin Tempe di Kelurahan Rajawali Kecamatan Jambi Timur Kota Jambi adalah konsumsi cairan dan beban kerja. Diharapkan pengrajin tempe untuk dapat mengkonsumsi cairan sesuai dengan kebutuhan tubuh, mengonsumsi air minum secara teratur dalam jumlah kecil sebelum merasa haus agar terhindar dari kejadian dehidrasi, menjaga kondisi kesehatannya dengan memanfaatkan waktu luang untuk istirahat yang cukup, mengkonsumsi makanan yang kaya nutrisi (protein hewani dan nabati). Peneliti juga berharap kepada pemilik usaha untuk selalu menyediakan air minum yang cukup bagi pekerjanya saat pekerja membutuhkan sehingga kejadian dehidrasi dan dampaknya dapat diminimalisir.

\section{UCAPAN TERIMAKASIH}

Diucapkan terimakasih kepada semua pihak yang telah berkontribusi dalam penelitian ini,dan juga terimakasih kepada seluruh pekerja tempe di kelurahan rajawali kecamatan Jambi Timur kota jambi, serta enumator yang telah mendampingi saya sehingga penelitian ini dapat terlaksanakan dengan baik dan berjalan lancar.

\section{DAFTAR PUSTAKA}

R., \& Soekatri, M. (2014). Hubungan Pola Minum Dan Jumlah Konsumsi Cairan Dari Minuman Terhadap Status Dehidrasi Santriwati Usia 16-18 Tahun Di Pondok Pesantren Darunnajah Jakarta Selatan Tahun 2012. Gizi Indonesia. https://doi.org/10.36457/gizindo.v35i2.128

Barasi. M. (2010). Nutrition at a Glance (Terjemahan oleh Hermin, 2009). Erlangga.

Brenna H. 2012. (2012). Nutrition Made Increadibly Easy Second Edition (Penerbit buku kedokteran GEC (ed.); Penerbit b). Penerbit buku kedokteran GEC.

Departemen Kesehatan. (2016). Pedoman Umum Gizi Seimbang (Pugs) (Departemen Kesehatan (ed.)). Departemen Kesehatan.

Fajriani, A., \& Septiari, D. (2015). Pengaruh beban pekerjaan terhadap kinerja karyawan: Efek mediasi burnout. Jurnal Akuntansi, Ekonomi Dan Manajemen Bisnis, 1 (3), 7479. https://jurnal.polibatam.ac.id/index.php/JAEMB/article/view/188/177.

Huda, A. I., \& Suwandi, T. (2018). Relations Between Workload and Consumption of Drinking Water With Dehydration in Workers of Tofu Factory. The Indonesian Journal of Occupational Safety and Health.

Nurmalia \& Nivalinda. (2016). Fungsi Manajemen Keperawatan Dalam Aplikasi Mentoring Budaya Keselamatan Pasien. Media Medika Muda, 2(2), 99-104.

Randa, R., Gifari, N., Nuzrina, R., \& Kuswari, M. (2018). Hubungan Status Gizi, Pengetahuan, Konsumsi Cairan, Lingkungan Kerja dan Status Hidrasi pada Karyawan. Jurnal Fakultas Ilmu Kesehatan.

Tarwiyanti, D., Hartanti, R. I., \& Indrayani, R. (2020). Beban Kerja Fisik dan Iklim Kerja dengan Status Hidrasi Pekerja Unit P2 Bagian (Wood Working 1) WW1 PT. KTI Probolinggo. Pustaka Kesehatan. https://doi.org/10.19184/pk.v8i1.11200 